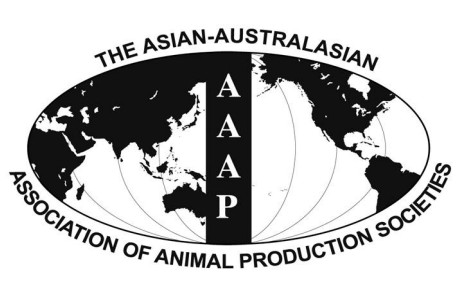

Open Access

Asian Australas. J. Anim. Sci.

Vol. 29, No. 2 : 257-262 February 2016

http://dx.doi.org/10.5713/ajas.15.0189

www.ajas.info

pISSN 1011-2367 elSSN 1976-5517

\title{
Quality Characteristics of Dry-cured Ham Made from Two Different Three-way Crossbred Pigs
}

\author{
Dong-Gyun Yim, Doo-Il Hong ${ }^{1}$, and Ku-Young Chung ${ }^{1, *}$ \\ Department of Health Administration and Food Hygiene, Jinju Health College, Jinju 660-757, Korea
}

\begin{abstract}
This study was conducted to compare the physicochemical traits of dry-cured hams made from two different three-way crossbred pigs: Yorkshire $\times$ Landrace $\times$ Duroc $(Y L D)$ and Yorkshire $\times$ Berkshire $\times$ Duroc $(Y B D)$. Animals were slaughtered at a live weight of 110 to $120 \mathrm{~kg}$ and cooled at $0^{\circ} \mathrm{C}$ for $24 \mathrm{~h}$ in a chilling room, the ham portion of the carcasses were cut and processed by dry-curing for physico-chemical analyses. While the moisture and crude protein contents of dry-cured ham were higher in YLD than in YBD, crude fat and ash content were higher in YBD $(p<0.05)$. The salt contents of ham from YBD were higher than those from YLD $(p<0.05)$. YBD ham samples showed a higher $L^{*}$ and $b^{*}$ values than those from YLD, while YBD ham showed lower $a^{*}$ value $(p<0.05)$. Thiobarbituric acid reactive substances (TBARS) and volatile basic nitrogen (VBN) values of YLD hams were lower than those of YBD samples $(\mathrm{p}<0.05)$. Hardness, gumminess, chewiness, and shear force values of YBD ham were higher than those of YLD sample $(\mathrm{p}<0.05)$. Saltiness was significantly higher in YBD ham than in YLD samples $(p<0.05)$. YLD ham displayed a superior quality than YBD. Considering the meat quality parameters of two-way crossbred ham, YLD hams could be more suitable for the production of dry-cured products. (Key Words: Crossbred Pig, Dry-cured Ham, Physico-chemical Trait)
\end{abstract}

\section{INTRODUCTION}

Dry-cured ham is one of the oldest cured meat products, which is made from whole leg of pork or other whole muscle (Jin et al., 2012). This is favorable to consumers due to the particular sensory characteristics and physicochemical and biochemical changes that take place during ripening period (Cava et al., 1999). The raw material is a decisive factor in the quality of dry-cured ham and depends on several factors, such as genetics type, sex, feeding, and rearing system (Hui et al., 2004).

Crossbreeding in pig production is aimed to increase the total efficiency and also to improve the quantity and quality of the meat (Sellier, 1998). Nowadays, the majority of pig production is based on crossbreds and generally is threeway crosses with Landrace $\times$ Yorkshire $\times$ Duroc $(L Y D)$ in Korea. These crossbreds have an excellent growth rate,

\footnotetext{
* Corresponding Author: Ku-Young Chun. Tel: +82-33-730-0534, Fax: +82-33-744-6118, E-mail: kychung@sangji.ac.kr

${ }^{1}$ Department of Animal Science and Biotechnology, Sangji University, Wonju 220-702, Korea.

Submitted Mar. 4, 2015; Revised May 2, 2015; Accepted May 23, 2015
}

higher yields and bigger litter size than other crossbreds (Lim et al., 2014). Individual breeds of pigs have their own different traits. Berkshire has both an excellent water holding capacity and higher amino acid contents. On the other hand, Duroc breed has both an excellent growth rate and a higher fat content relative to the Landrace and Yorkshire. Landrace pigs have a thin subcutaneous fat layer, large hams and high muscularity in the carcass (Lim et al., 2014). Traditionally, common crossbreeding used in Europe for the production of high quality dry-cured ham is Yorkshire $\times$ Berkshire $\times$ Duroc $(Y B D)$.

Different genetic groups of pigs have been used to obtain fresh hams with ideal quality traits and, in particular, crossbreds often satisfies both muscle and fat quality criteria for dry-ham processing (Sabbioni et al., 2004). Parameters, such as texture, color and intramuscular fat, are used as quality indicators of dry-cured ham (Ruiz-Ramirez et al., 2006). Dry-cured ham has been largely studied for its physico-chemical and sensory properties and for the variation of its sensory quality depending on processing technologies (Andrés et al., 2004; Serra et al., 2005). It is worthwhile to investigate the meat quality of different types 
of crossbreeds required to fulfill the diversity of consumers' options. However, very few studies have been made on the quality characteristics of dry-cured hams from three-way crossbreeds: YLD and YBD. Therefore, the aim of this study was to assess the influence of crossbreeding on the quality traits of dry-cured ham, as well as acceptability of dry-cured hams produced from these pigs.

\section{MATERIALS AND METHODS}

\section{Animals, sample collection and processing of the hams}

A total of 20 gilts, 180 days old, were evaluated from crossbreeding schemes which included YLD and YBD with animals in each scheme. The pigs were born and raised at swine farms. Animals were fed the same commercial feed including the fattening period from weaning weight $(30 \mathrm{~kg})$ to slaughter weight $(90 \mathrm{~kg})$. These pigs were housed in partially slotted and concrete floor pens having a pen size of $3.5 \mathrm{~m} \times 3.5 \mathrm{~m}$. Pens were equipped with a self-feeder and nipple waterer to allow ad libitum access to feed and water. Animals were fed a commercial feed ad libitum with a composition of $17 \%$ protein, $2.4 \%$ fat and $3,250 \mathrm{kcal} / \mathrm{kg}$ metabolic energy. Pigs from each crossbred were randomly selected from 110 to $120 \mathrm{~kg}$ range of marketing weight, slaughtered, and cooled at $0^{\circ} \mathrm{C}$ for $24 \mathrm{~h}$ in a chilling room. The carcasses were deboned and the left hind legs were used. After they were thoroughly rubbed with a mixture of $50 \mathrm{~g}$ domestic sun-dried salt per $\mathrm{kg}$ of pork hind leg, they were stored in a salting chamber at a relative humidity $(\mathrm{RH})$ of $75 \pm 5 \%$ and a temperature of $3 \pm 1{ }^{\circ} \mathrm{C}$ for 60 days. After salting, the samples were soaked in cold water and washed. Subsequently, hind legs were dried for 60 days at $20^{\circ} \mathrm{C}$ $\pm 3^{\circ} \mathrm{C}$ and at $80 \%$ to $100 \%$ RH. Finally, they were ripened for 60 additional days at $10^{\circ} \mathrm{C} \pm 6^{\circ} \mathrm{C}$ and at $65 \%$ to $75 \% \mathrm{RH}$. After the ripening stage, the muscles were sliced $(10 \mathrm{~cm}$ thickness) using a slicer (Fujee Co., Seoul, Korea). Before analysis, the fat was manually removed from the ham slices using a knife. All determinations were carried out on the homogenized sample, in triplicate.

\section{Proximate composition and $\mathrm{pH}$}

The proximate composition was obtained with a slightly modified method of AOAC (AOAC, 2000). Briefly, the moisture content was obtained by drying each sample $(3 \mathrm{~g})$ placed in an aluminum dish at $104^{\circ} \mathrm{C}$ for $15 \mathrm{~h}$. The crude protein contents were measured by the Kjeldahl method (VAPO45, Gerhardt Ltd., Idar-Oberstein, Germany). The crude fat contents were measured using the Soxhlet extraction system (TT 12/A, Gerhardt Ltd., Germany). The crude ash content was measured by igniting $2 \mathrm{~g}$ of each sample in a furnace at $600^{\circ} \mathrm{C}$ overnight.

The $\mathrm{pH}$ of samples was measured in triplicate using a digital $\mathrm{pH}$ meter (Orion 2 Star, Thermo scientific, Beverly, MA, USA). A slurry was prepared by blending a $10 \mathrm{~g}$ drycured ham sample with $90 \mathrm{~mL}$ distilled water for $60 \mathrm{~s}$ in a homogenizer (Polytron PT 10-35 GT, Kinematica AG, Switzerland). The electrode was calibrated with $\mathrm{pH} 4.01$ and 7.00 standard buffers equilibrated at $25^{\circ} \mathrm{C}$ for the measurements. Water activity of ham was determined with a water activity meter (Handheld instrument HP23-AW-A Instrument, Rotronic AG, Zurich, Switzerland).

\section{Water-holding capacity, salt content and meat color}

Water-holding capacity was measured using the method of Ryoichi et al. (1993), with minor modifications. Samples were placed in preweighed centrifugal microfilters (Centrex glass fiber filter, Schleicher \& Schuell, St. Louis, MO, USA) without the collection vial, and weighed. The vial was attached, and tubes centrifuged at 2,000 g for $15 \mathrm{~min}$. The collection vial containing the expressed fluid was removed, and tubes reweighed, enabling water loss to be calculated by difference. The water holding capacity (\%) was calculated as the percentage of remaining water content of meat samples after centrifugation.

Salt content was determined by a digital analyzer (PAL03S, ATAGO, Tokyo, Japan). The surface color value of the samples were measured using the Commission Internationale de l'Eclairage $\mathrm{L}^{*}, \mathrm{a}^{*}$ and $\mathrm{b}^{*}$ system using a Minolta chromameter (Model CR-410, Minolta Co., Tokyo, Japan), with measurements standardized with respect to a white calibration plate $\left(\mathrm{L}^{*}=89.2, \mathrm{a}^{*}=0.921, \mathrm{~b}^{*}=0.783\right)$ after $30 \mathrm{~min}$ blooming at room temperature. Color measurements always trying to avoid area with excess fat were taken and the value was recorded.

\section{Thiobarbituric acid reactive substances and volatile basic nitrogen values}

The thiobarbituric acid reactive substances (TBARS) values of samples were analyzed by the modified method described by Witte (1970). A dry-cured ham sample of $5 \mathrm{~g}$ was weighed into a $50 \mathrm{~mL}$ test tube and homogenized with $15 \mathrm{~mL}$ of deionized distilled water using the Polytron homogenizer for $15 \mathrm{~s}$ at the highest speed (T25basic, IKA, Selangor, Malaysia). The ham sample homogenate $(2 \mathrm{~mL})$ was transferred to a disposable test tube $\left(13 \times 100 \mathrm{~mm}^{2}\right)$, and a butylated hydroxyanisole $(10 \%, 50 \mathrm{~mL})$ and thiobarbituric acid/trichloroacetic acid (TBA/TCA) solution $(4 \mathrm{~mL})$ were added. The sample was mixed using a vortex mixer, and it was then incubated in a boiling water bath for $15 \mathrm{~min}$ to develop color. The sample was cooled and determined at $531 \mathrm{~nm}$ against a blank containing $2 \mathrm{~mL}$ of deionized distilled water and $4 \mathrm{~mL}$ of TBA/TCA solution. The amounts of TBARS were expressed in $\mathrm{mg}$ of malondialdehyde (MDA) per $\mathrm{kg}$ of sample. The micro- 
diffusion method described by Conway (1950) was modified for the determination of volatile basic nitrogen values $(\mathrm{VBN})$ in the dry-cured ham samples. Each ham sample (3 g) was homogenized (Ultra-turrax T25-S1, IKA, Staufen, Germany) for $30 \mathrm{~s}$ with $27 \mathrm{~mL}$ of distilled water. The supernatant solution was filtered using a filter paper (No.4, Whatman, St. Louis, MO, USA). Ten $\mathrm{mL}$ of $20 \mathrm{~g} / \mathrm{L}$ boric acid was placed on the inner section of a Conway micro-diffusion cell (Sibata Ltd., Tokyo, Japan). Then $1 \mathrm{~mL}$ of sample solution and $1 \mathrm{~mL}$ of saturated $\mathrm{K}_{2} \mathrm{CO}_{3}$ solution were also placed on the outer section of the same cell, and the lid was immediately closed. The cell was incubated at $25^{\circ} \mathrm{C}$ for $60 \mathrm{~min}$, and it was then titrated against $0.02 \mathrm{~N}$ $\mathrm{H}_{2} \mathrm{SO}_{4}$. The VBN value was calculated by the following equation:

$$
\begin{aligned}
& \text { VBN mg } \%(\mathrm{mg} / 100 \mathrm{~g} \text { sample }) \\
& =[(\mathrm{a}-\mathrm{b}) \times \mathrm{f} \times 28.014] / \mathrm{S} \times 100
\end{aligned}
$$

Where $\mathrm{S}$ is the meat sample weight in grams, $\mathrm{b}$ is the volume of added $\mathrm{H}_{2} \mathrm{SO}_{4}$ in blank in $\mathrm{mL}$, a is the volume of added $\mathrm{H}_{2} \mathrm{SO}_{4}$ in the sample in $\mathrm{mL}$, and $\mathrm{f}$ is the standard factor of $\mathrm{H}_{2} \mathrm{SO}_{4}$.

\section{Instrumental texture analysis}

Texture measurements in the form of texture profile analysis (TPA; Bourne, 1978) of the hams were performed at room temperature with a TA-XT2 Texture Analyzer (Stable Micro Systems, Godalming, UK) with a 2,500 N load cell. The Texture Expert, version 1.20 (Spanish), computer program by Stable Micro Systems was used for data collection and calculations. The samples were $1 \mathrm{~cm}$ in height and $1.5 \mathrm{~cm}$ in diameter. Each sample was compressed axially in two consecutive cycles of $50 \%$ compression with a flat plunger $50 \mathrm{~mm}$ in diameter (P50), with $5 \mathrm{~s}$ between cycles. The cross-head moved at a constant speed of $1 \mathrm{~mm} / \mathrm{s}$. The following texture parameters were measured from force-deformation curves: hardness, springiness, cohesiveness, gumminess and chewiness. Shear force values $(\mathrm{kg})$ were also analyzed with the same analyzer.

\section{Sensory evaluations}

All the samples, with $1.5 \mathrm{~mm}$ thickness, were evaluated at $20^{\circ} \mathrm{C}$ to $22^{\circ} \mathrm{C}$ in a sensory panel room. About $50 \mathrm{~mL}$ of water and $20 \mathrm{~g}$ of unsalted bread were provided to assessors between successive ham samples. During the sensory training sessions there were both discussion and sensory assessment of representative samples. The attributes flavor, juiciness, tenderness, saltiness and acceptability were assessed. The sensory scores were evaluated independently by 10 trained sensory panelists for random cubes of each sample using a seven-point quantitative descriptive method, varying from very low (score 1) to very high (score 7)

\section{Statistical methods}

An analysis of variance was performed on all the variables measured using the general linear model procedure of the SAS statistical package (SAS Institute Inc. 2002). The t-test $(p<0.05)$ was used to determine differences among the treatment means. Mean values and standard deviations were reported.

\section{RESULTS AND DISCUSSION}

\section{Physico-chemical characteristics}

Comparison of proximate composition of dry-cured ham made from YLD and YBD is shown in Table 1. Crossbred differences in proximate composition were found $(p<0.05)$. While the moisture and crude protein contents of dry-cured ham were higher in hams made from YLD than in YBD, crude fat and ash contents were higher in YBD. Seong et al. (2008) reported that the moisture, fat and protein contents of the muscles biceps femoris from cooked dry-cured ham were $66.9 \%, 7.3 \%$, and $22 \%$ respectively. Fuentes et al. (2014) observed that moisture and fat content of the muscle biceps femoris from dry-cured hams produced from crossbred ranged from $48 \%$ to $51 \%$ and from $5.7 \%$ to $7.1 \%$, respectively. Ventanas et al. (2006) showed that the genetic background significantly affects the proximate composition of dry-cured hams. Kim et al. (2007) stated that the butts from the Berkshire $\times$ Duroc $(\mathrm{BD})$ had higher fat contents than Yorkshire $\times$ Landrace $\times$ Berkshire $($ YLB) and YLD. Fat content is believed to be one of the most crucial quality traits of cured hams. Jiménez-Colmenero et al. (2010) mentioned that the higher the fat content, the greater the acceptability of dry-cured hams.

The water activity of dry-cured hams made from crossbreeds ranged from $0.84 \%$ to $0.85 \%$ in this study. Similar values were found for dry-cured hams by Jin et al. (2012). Lorenzo et al. (2008) suggested that the water activity values of dry-cured meat products decreased progressively and significantly throughout the whole manufacturing process. The water activity is useful to

Table 1. Proximate composition (\%) of dry-cured ham made from two different three-way crossbreed pigs

\begin{tabular}{lrr}
\hline \multirow{2}{*}{ Variable } & \multicolumn{2}{c}{ Crossbred } \\
\cline { 2 - 3 } YLD $^{1}$ & \multicolumn{1}{c}{ YBD } \\
\hline Moisture & $56.00 \pm 0.60^{\mathrm{a}}$ & $53.89 \pm 0.60^{\mathrm{b}}$ \\
Crude protein & $28.04 \pm 0.05^{\mathrm{a}}$ & $26.87 \pm 0.07^{\mathrm{b}}$ \\
Crude fat & $3.24 \pm 0.21^{\mathrm{b}}$ & $6.17 \pm 0.63^{\mathrm{a}}$ \\
Crude ash & $11.86 \pm 0.03^{\mathrm{b}}$ & $13.00 \pm 0.02^{\mathrm{a}}$
\end{tabular}

YLD, Yorkshire $\times$ Landrace $\times$ Duroc; YBD, Yorkshire $\times$ Berkshire $\times$ Duroc Values are mean \pm standard deviation.

${ }^{a, b}$ Means with different letters within a same row differ significantly $(\mathrm{p}<0.05)$. 
describe the equilibrium state of dry-cured ham, and hams must have a stable water activity value to avoid changes in quality during storage (Jin et al., 2012). Many researchers have indicated that the production of lactic acid in tissue leads to a reduction in $\mathrm{pH}$ of meat, which leads to a reduced amount of water (Lorenzo et al., 2008). Salt, which is a multifunctional ingredient in dry-cured ham elaboration, affects both quality and safety. YBD ham contained a much higher salt content than YLD $(\mathrm{p}<0.05)$. The $\mathrm{NaCl}$ final concentration depends on the degree of dryness at the end of ripening (Zanardi et al., 2010).

Regarding color measurement, YBD ham samples showed a significantly higher $\mathrm{L}^{*}$ and $\mathrm{b}^{*}$ values than YLD, while YBD ham showed a lower $a^{*}$ value $(p<0.05)$. Lightness is related to the thin aqueous layer on the muscle's surface (Hunt, 1980). These results suggest that lightness in these muscles depends on the water content (moisture) and water movement (dehydration) towards the surface (Marusic et al., 2011).

Lipid oxidation measured as TBARS is a major factor in reducing quality and acceptability of meat products (Morrissey et al., 1998). As presented in Table 2, YBD ham showed significantly higher TBARS value than YLD samples $(\mathrm{p}<0.05)$. This indicates that YBD ham is more susceptible to lipid oxidation than YLD (Lim et al., 2014). This could be explained by the fact YLD had less oxidative fiber type than YBD. $\mathrm{NaCl}$ has a significant pro-oxidant effect in meat and meat products and salt accelerates lipid oxidation but the mechanism of action is not fully elucidated (Kanner et al., 1991). However, there is evidence that chloride ions may displace iron ions from binding macromolecules and make them available as initiators of lipid peroxidation (Kanner et al., 1991). The VBN value of the YLD sample was significantly lower than that of the

Table 2. Quality traits of dry-cured ham made from two different three-way crossbreed pigs

\begin{tabular}{lrr}
\hline \multirow{2}{*}{ Variable } & \multicolumn{2}{c}{ Crossbred } \\
\cline { 2 - 3 } & \multicolumn{1}{c}{ YLD } & \multicolumn{1}{c}{ YBD } \\
\hline pH & $5.83 \pm 0.01$ & $5.74 \pm 0.01$ \\
Water holding capacity & $24.36 \pm 0.51$ & $23.70 \pm 0.75$ \\
Water activity & $0.85 \pm 0.05$ & $0.84 \pm 0.03$ \\
Salt content (\%) & $14.15 \pm 0.07^{\mathrm{b}}$ & $17.30 \pm 0.01^{\mathrm{a}}$ \\
CIE L* $^{*}$ & $49.02 \pm 0.46^{\mathrm{b}}$ & $53.33 \pm 0.91^{\mathrm{a}}$ \\
CIE a* $^{*}$ & $14.12 \pm 0.35^{\mathrm{a}}$ & $12.43 \pm 0.31^{\mathrm{b}}$ \\
CIE b* $^{*}$ & $1.27 \pm 0.22^{\mathrm{b}}$ & $2.84 \pm 0.22^{\mathrm{a}}$ \\
TBA (mg malonedialdehyde/kg) & $2.02 \pm 0.13^{\mathrm{b}}$ & $2.34 \pm 0.13^{\mathrm{a}}$ \\
VBN (mg/\%) & $44.65 \pm 0.49^{\mathrm{b}}$ & $51.67 \pm 0.50^{\mathrm{a}}$
\end{tabular}

YLD, Yorkshire $\times$ Landrace $\times$ Duroc; YBD, Yorkshire $\times$ Berkshire $\times$ Duroc; CIE, Commission Internationale de l'Eclairage; TBA, thiobarbituric acid; VBN, volatile basic nitrogen.

Values are mean \pm standard deviation.

${ }^{a, b}$ Means with different letters within a same row differ significantly $(\mathrm{p}<0.05)$.
Table 3. Texture profile of dry-cured ham made from two different three-way crossbreed pigs

\begin{tabular}{|c|c|c|}
\hline \multirow{2}{*}{ Variable } & \multicolumn{2}{|c|}{ Crossbred } \\
\hline & YLD & YBD \\
\hline Hardness (kg) & $29.90 \pm 1.31^{\mathrm{b}}$ & $33.15 \pm 0.61^{\mathrm{a}}$ \\
\hline Springiness (mm) & $0.50 \pm 0.13$ & $0.60 \pm 0.08$ \\
\hline Cohesiveness (mm) & $0.65 \pm 0.08$ & $0.68 \pm 0.03$ \\
\hline Gumminess (mm) & $19.34 \pm 0.77^{\mathrm{b}}$ & $20.77 \pm 0.33^{\mathrm{a}}$ \\
\hline Chewiness (mm) & $9.56 \pm 0.32^{b}$ & $11.70 \pm 0.91^{\mathrm{a}}$ \\
\hline Shear force $(\mathrm{kg})$ & $14.76 \pm 0.51^{\mathrm{b}}$ & $18.48 \pm 0.48^{\mathrm{a}}$ \\
\hline
\end{tabular}

YLD, Yorkshire $\times$ Landrace $\times$ Duroc; YBD, Yorkshire $\times$ Berkshire $\times$ Duroc.

Values are mean \pm standard deviation.

a,b Means with different letters within a same row differ significantly $(\mathrm{p}<0.05)$.

YBD $(p<0.05)$. The VBN is an important index for estimation of meat freshness, because it is increased by the levels of microbial contamination (Lee and Joo, 1999).

\section{Texture profile and sensory evaluations}

For texture profile analysis, hardness, gumminess, chewiness, and shear force values were significantly higher in YBD ham than in YLD samples $(\mathrm{p}<0.05)$, as shown in Table 3. Texture is a major sensory characteristic in drycured ham quality evaluation. The main texture defects in dry-cured ham are excessive softness inside (Parolari, 1996). Numerous studies have demonstrated that negative correlations between moisture content and texture profile including hardness, gumminess and chewiness (Virgili et al., 1995; Monin et al., 1997; Serra et al., 2005). Similar finding was reported by Hui et al. (2004), who found that Biceps femoris muscles from hams with a higher salt content were the higher hardness. Warner-Bratzler shear force value is a moderate indicator of chewiness.

In case of sensory properties, there were no significant differences between YBD and YLD samples except the saltiness (Table 4). Saltiness was significantly higher in YBD ham than in YLD samples $(\mathrm{p}<0.05)$. Salt is not the only factor determining salty taste. This attribute can also be influenced by other kind of compounds such as amino

Table 4. Sensory evaluations of dry-cured ham made from two different three-way crossbreed pigs

\begin{tabular}{|c|c|c|}
\hline \multirow{2}{*}{ Variable } & \multicolumn{2}{|c|}{ Crossbred } \\
\hline & YLD & YBD \\
\hline Tenderness & $2.60 \pm 0.52^{1}$ & $2.20 \pm 0.42$ \\
\hline Flavor & $3.00 \pm 0.82$ & $3.30 \pm 0.95$ \\
\hline Juiciness & $3.60 \pm 0.97$ & $3.50 \pm 0.85$ \\
\hline Saltiness & $5.80 \pm 0.79^{\mathrm{b}}$ & $7.40 \pm 0.70^{\mathrm{a}}$ \\
\hline Overall acceptability & $3.40 \pm 0.97$ & $3.20 \pm 0.79$ \\
\hline
\end{tabular}

YLD, Yorkshire $\times$ Landrace $\times$ Duroc; YBD, Yorkshire $\times$ Berkshire $\times$ Duroc.

${ }^{1}$ 1: extremely low to 7 : extremely high.

Values are mean \pm standard deviation.

a,b Means with different letters within a same row differ significantly $(p<0.05)$. 
acids or nucleotides having a salty taste or a low proportion of intramuscular fat (Buscailhon et al., 1995). Ventanas et al. (2006) confirmed that crossbreeding influence both consumer preference and juiciness ranking. Intramuscular fat plays a decisive role in most features of dry-cured products directly linked to their sensory characteristics, such as marbling and juiciness (Ruiz et al., 2002). However, sensory characteristics appeared to be not related to higher fat content in this study. Further research should be required to verify on the meat quality of crossbred hams.

\section{CONCLUSION}

It can be concluded that two different three-way crossbreeding altered meat quality to some extent. It is conceivable that dry-cured hams from YLD pigs showed relatively desirable meat quality parameters in terms of higher moisture and protein and less TBARS and VBN. The present study confirms that YLD hams could be more suitable for the production of dry-cured products. The result of this study indicates that the meat quality of dry-cured ham could be improved by pig crossbreeding.

\section{CONFLICT OF INTEREST}

We certify that there is no conflict of interest with any financial organization regarding the material discussed in the manuscript.

\section{ACKNOWLEDGMENTS}

This research was supported by research funds of Sangji University.

\section{REFERENCES}

Andrés, A. I., R. Cava, J. Ventanas, V. Thovar, and J. Ruiz. 2004. Sensory characteristics of Iberian ham: Influence of salt content and processing conditions. Meat Sci. 68:45-51.

AOAC. 2000. Official Methods of Analysis. 17th edn. Association of Official Analytical Chemists, Gaithersburg, MD, USA.

Bourne, M. C. 1978. Texture profile analysis. Food Technol. 32:72.

Buscailhon, S., C. Touraille, J. P. Girard, and G. Monin. 1995. Relationship between muscle tissue characteristics and sensory quality of dry-cured ham. J. Muscle Foods 6:9-22.

Cava, R., J. Ruiz, J. Ventanas, and T. Antequera. 1999. Oxidative and lipolytic changes during ripening of Iberian hams as affected by feeding regime: Extensive feeding and alphatocopheryl acetate supplementation. Meat Sci. 52:165-172.

Conway, E. J. 1950. Microdiffusion analysis and volumetric error. 3rd ed. Crosby Lockwood and Son Ltd, London, UK.

Fuentes, V., S. Ventanas, J. Ventanas, and M. Estevez. 2014. The genetic background affects composition, oxidative stability and quality traits of Iberian dry-cured hams: purebred Iberian versus reciprocal Iberian $\times$ Duroc crossbred pigs. Meat Sci.
96:737-743.

Hunt, M. C. 1980. Meat color measurements. Proceedings of 33rd Annual Reciprocal Meat Conference, Chicago, IL, USA.

Jiménez-Colmenero, F., J. Ventanas, and F. Toldrá. 2010. Nutritional composition of dry- cured ham and its role in a healthy diet. Meat Sci. 84:585-593.

Jin, S. K., C. W. Kim, K. H. Chung, K. K. Jo, J. Y. Jeong, I. C. Hur, E. Y. Jung, S. T. Joo, and H. S. Yang. 2012. Physicochemical and sensory properties of irradiated dry-cured ham. Radiat. Phy. Chem. 81:208-215.

Kanner, J., S. Harel, and R. Joffe. 1991. Lipid peroxidation of muscle food as affected by $\mathrm{NaCl}$. J. Agric. Food Chem. 39:1017-1024.

Kim, H. S., H. S. Yang, J. I. Lee, S. T. Joo, J. T. Jeon, and J. G. Lee. 2007. Effects of the mating system on retail cut yield and meat quality in commercial pigs. J. Anim. Sci. Technol. 49:379-386.

Lee, J. G. and S. T. Joo. 1999. Effects of slaughter weight on backfat thickness, intramuscular fat and physical properties of pork loin from barrow. Korean J. Anim. Sci. 41:207-214.

Lim, D. G., C. Jo, K. S. Seo, and K. C. Nam. 2014. Comparison of meat quality of loins and butts in different two-way crossbred pigs. Livest. Sci. 161:210-217.

Lorenzo, J. M., M. C. G. Fontan, I. Franco, and J. Carballo. 2008. Biochemical characteristics of dry-cured lacon (a Spanish traditional meat product) throughout the manufacture, and sensorial properties of the final product. Effect of some additives. Food Control 19:1148-1158.

Marusic, N., M. Petrovic, S. Vidacek, T. Petrak, and H. Medic. 2011. Characterization of traditional Istrian dry-cured ham by means of physical and chemical analyses and volatile compounds. Meat Sci. 88:786-790.

Monin, G., P. Marinova, A. Talmant, J. F. Martin, M. Cornet, D. Lanore, and F. Grasso. 1997. Chemical and structural changes in dry-cured hams (Bayonne Hams) during processing and effects of dehairing technique. Meat Sci. 47:29-47.

Morrissey, P. A., P. J. Sheehy, K. Galvin, J. P. Kerry, and D. J. Buckley. 1998. Lipid stability in meat and meat products. Meat Sci. 49:73-86.

Parolari, G. 1996. Review: Achievements, needs and perspectives in dry-cured ham technology: The example of Parma ham. Food Sci. Technol. Int. 2:69-78.

Ruiz, J., C. Garcia, E. Muriel, A. I. Andres, and J. Ventanas. 2002. Influence of sensory characteristics on the acceptability of drycured ham. Meat Sci. 61:347-354.

Ruiz-Ramirez, J., J. Arnau, X. Serra, and P. Gou. 2006. Effect of $\mathrm{pH}$ (24), $\mathrm{NaCl}$ content and proteolysis index on the relationship between water content and texture parameters in biceps femoris and semimembranosus muscles in dry-cured ham. Meat Sci. 72:185-194.

Ryoichi, S., T. Degychi, and Y. Nagata. 1993. Effectiveness of the filter paper press methods for determining the water holding capacity of meat. Fleischwirtsch 73:1399.

SAS Institute Inc. 2002. SAS/STAT Software for PC. Release 6.11. SAS Institute Inc., Cary, NC, USA.

Sabbioni, A., V. Beretti, A. Zanon, P. Superchi, C. Sussi, and A. Bonomi. 2004. Effect of the proportion of Duroc genes in crosses with Large White and Landrace pigs on the characteristics of seasoned Parma ham. Italian J. Animal Sci. 3:31-39. 
Sellier, P. 1998. Genetics of meat and carcass traits. In: The genetics of the pig (Eds. M. F. Rothschild and A. Ruvinski). CAB International, Wallingford, UK. pp. 463-510.

Seong, P. N., S. H. Cho, J. H. Kim, K. H. Hah, B. Y. Park, D. H. Kim, J. M. Lee, and C. N. Ahn. 2008. Quality attributes of cooked pork hams manufactured with major hind leg muscles and Longissimus dorsi. Korean J. Food Sci. An. 28:160-164.

Serra, X., J. Ruiz-Ramirez, J. Arnau, and P. Gou. 2005. Texture parameters of dry-cured ham $\mathrm{m}$. biceps femoris samples dried at different levels as a function of water activity and water content. Meat Sci. 69:249-254.

Hui, Y. H., L. Meunier-Goddik, A. S. Hansen, J. Josephsen, W. K. Nip, P. S. Stanfield, and F. Toldrá. 2004. Handbook of food and beverage fermentation technology. Marcel-Dekker Inc., New York, NY, USA.
Ventanas, S., J. Ventanas, A. Jurado, and M. Estévez. 2006. Quality traits in muscle biceps femoris and back-fat from purebred Iberian and reciprocal Iberian $\times$ Duroc crossbred pigs. Meat Sci. 73:651-659.

Virgili, R., G. Parolari, C. Schivazappa, C. S. Bordini, and M. Borri. 1995. Sensory and texture quality of dry-cured ham as affected by endogenous cathepsin B activity and muscle composition. J. Food Sci. 60:1183-1186.

Witte, V. C. 1970. A new extraction method for determining 2thiobarbituric acid values of pork. Food Technol. 8:326.

Zanardi, E., S. Ghidini, M. Conter, and A. Ianieri. 2010. Mineral composition of Italian salami and effect of $\mathrm{NaCl}$ partial replacement on compositional, physico-chemical and sensory parameters. Meat Sci. 86:742-747. 